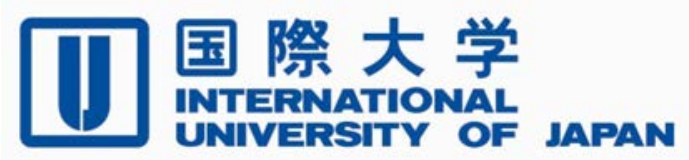

Economics \& Management Series

EMS-2016-05

\title{
Accountability, Political Views, and Bureaucratic Be- havior: A Theoretical Approach
}

Sangyub Ryu

Hankuk University of Foreign Studies

\author{
Yongjin Chang \\ International University of Japan
}

April 2016

IUJ Research Institute

International University of Japan

These working papers are preliminary research documents published by the IUJ research institute. To facilitate prompt distribution, they have not been formally reviewed and edited. They are circulated in order to stimulate discussion and critical comment and may be revised. The views and interpretations expressed in these papers are those of the author(s). It is expected that the working papers will be published in some other form. 


\title{
Accountability, Political Views, and Bureaucratic Behavior: \\ A Theoretical Approach
}

\author{
Sangyub Ryu ${ }^{1} \&$ Yongjin Chang ${ }^{2}$
}

\begin{abstract}
This study aims to theoretically develop a framework to predict bureaucratic behaviors with the political view dimension and the accountability dimension by adopting and extending Hirschman’s (1970) exit, voice, and loyalty. The political ideology dimension is dichotomized based on whether a bureaucrat's political ideology is congruent or incongruent with his/her overhead political principals. The bureaucratic accountability dimension is also dichotomized between accountability to the overhead political principals and accountability to the public sentiment. With the given dimensions, the exit, voice, loyalty, and silence scenarios are discussed as possible bureaucratic behaviors. In addition, the stay scenario is discussed for passive bureaucrats regardless of the two dimensions. By incorporating studies on bureaucrats’ political views, accountability, and Hirschman’s bureaucratic behaviors, this study expects to contribute to a better understanding of bureaucrats.
\end{abstract}

\section{Introduction}

Congress has historically prohibited Bureaucrats from engaging in political activity in order to shield bureaucrats from political pressure. However, this prohibition on bureaucrats’ political activity has been challenged regularly in court (Nigro, Nigro, and Kellough, 2007), Today, political neutrality is no longer a salient feature of

\footnotetext{
${ }^{1}$ Assistant Professor in the Department of Public Administration, Hankuk University of Foreign Studies

${ }^{2}$ Assistant Professor in the Graduate School of International Relations, International University of Japan
} 
bureaucrats. The Hatch Act Reform Amendments of 1993 opened the gate to political participation for public employees "to exercise fully, freely, and without fear of penalty or reprisal, and the extent not expressly prohibited by law, their right to participate or refrain from participating in the political processes” (U.S. Office of Personnel Management, 1998). Although bureaucrats are still prohibited from engaging in political activities while on duty, they commonly express their opinions about political issues while not on duty. ${ }^{3}$ As a result, the Hatch Act Reform Amendment leads scholars of public administration to an interesting question: What happens if bureaucrats have similar, or different, views on political issues to their overhead political appointees? This study discusses different bureaucratic behaviors based on congruence or incongruence between bureaucrats' political views and their overhead political appointees’ political views.

In addition to the two different scenarios mentioned above, this study employs the accountability dimension to understand bureaucratic behavior. According to the literature, bureaucrats are accountable to generally two different principals — the general public and their overhead political appointees (Finer, 1936; Friederich, [1940] 1965). It is assumed that depending on to whom bureaucrats are accountable, bureaucrats may behave in different ways.

This study aims to theoretically develop a framework to predict bureaucratic behaviors with the political view dimension and the accountability dimension by adopting and extending Hirschman’s (1970) exit, voice, and loyalty. The current study on political views, accountability, and bureaucratic behaviors may attract scholars' attention because no study thus far has discussed bureaucratic behaviors based on the given dimensions even though each dimension has been actively

\footnotetext{
3 “The Hatch Act: Political Activity and the Federal Employee,” U.S. Food and Drug Administration. http://www.fda.gov/AboutFDA/WorkingatFDA/Ethics/ucm071602.htm, (March26, 2015).
} 
researched. By incorporating studies on bureaucrats’ political views, accountability, and Hirschman's bureaucratic behaviors, this study expects to contribute to a better understanding of bureaucrats.

\section{Political Views of Career Bureaucrats}

In general, career bureaucrats are politically neutral by law. However, this does not necessarily mean that each public official should be apolitical. Moreover, the Hatch Act Reform Amendment of 1993 permits most federal employees to actively participate in political activities such as attending political fundraising functions, joining political party, or holding office in political parties. Bureaucrats’ political ideology and behavior is important in the sense that they can control elected officials who directly control them (Hunter and Ranking, 1988; O’Brien, 1992; Zax, 1988). Even if career bureaucrats should maintain a politically neutral position in office, they may experience an inner-conflict between their role as public officers and their role as citizens. Public officials are definitely a part of political and policy processes, as they should be (Fry \& Nigro 1993). In this section, we briefly examine political postures of bureaucrats from Weberian’s view, public-administration dichotomy, political pluralists, new public administration, public choice, and new public management. According to Weber's ideal type of bureaucracy, public officials should be neutral and impartial to special interests, as well as loyal to elected political authorities, showing unquestioned obedience in order to provide for the public good (de Graaf 2010; Wise 2004). Bureaucrats in Weberian’s view are assumed to carry out their duties with “objectivity”, “expertise”, and "professionalism”, without anger and passion (Jensen, Sum, \& Flynn 2009, 709; Fry \& Nigro 1996). Public officials in this view, therefore, should be separated from political arena and neutrally handle 
political matters. The appropriate role of bureaucrats is in the impersonal and passionless application of rules and laws. The honor of bureaucrats is in the conscious implementation of the lawful orders from high-level authorities (Fry \& Nigro 1996). Public officials from Weberian's perspective, therefore, do not have room to voice their political beliefs and participate in political activities.

Politics-administration dichotomy, an instrumental view of the role of public officials developed by civil service reformers during 1870s and 1880s and paramount from the late 1920s to 1930s in the USA, is based on a tenet similar to the Weberian bureaucracy (Fry \& Nigro 1996; Rosenbloom 1993; Svara 2001: 177). In “The Study of Administration” Woodrow Wilson argued, "the field of administration is a field of business. It is removed from the hurry and strife of politics" and "administrative questions are not political questions” (Wilson 1887, 209-210). Goodnow (1900, 35) also stated, "politics has to do with policies or expressions of the state will. Administration has to do with the execution of these policies.” Under the politicsadministration dichotomy, public officials "should be neutral in matters of policy" and only select appropriate means to implement the policies decided by their political superiors (Fry \& Nigro 1996. 39). The politics-administration dichotomy, however, became untenable after World War II as it was rejected by a series of scholars such as Dwight Waldo, Paul Appleby, Robert Dahl, and Norton Long (Rosenbloom 2008). Even though the idea was rejected widely after 1940’s (Fry \& Nigro 1996) and very few scholars agree to the perspective today, O’Toole $(1987,23)$ argued the dichotomy “remain remarkably true to American constitutional heritage and experience”, and Svara (2001) identified a number of reasons why the myth of the dichotomy is important in the public administration field. 
Objections to the dichotomy since the 1940s have come in many different forms. For example, Carl Friedrich overtly recognized the role of public administrators in the political process and suggested public officials should behave like policy advocates in order to be responsible to the public (Fry \& Nigro 1996). Political pluralists also proposed that "administrators are, and should be, involved in policy and political processes.” They regard public officials as "an extension of the pluralist political process” (Fry \& Nigro 1996, 43). David Rosenbloom (1993, 506) suggested, "public administration is an intensively political process that should be responsive to interested publics and legislators. In consequences, the legislature and the bureaucracy will tend to merge in a political and institutional sense, as do interest groups and agencies.” The New Public Administration (NPA), which took form during the late 1960s and early 1970s, also rejected the value of neutral bureaucrats and emphasized the role of public officials as advocates for a more just system. Administrators in the NPA should promote the value of equity, citizen participation, and justice for the politically powerless (Cooper, Bryer, \& Meek 2006; Frederickson 1976; Svara 1985; Whicker, Olshfski, \& Strickland, 1993).

Another example of disagreement with the politically neutral role of bureaucrats in public policy process is public-choice theory. The underlying premise of the theory is that public officials are motivated by "self-interest” and "personal gain” (Wise 2004, 673). The theory could explain the behavior of "politicos" who are eager "to maximize their political position or status" (Wise 2004, 673). Bureaucrats, in this theory, try to maximize their own interests by increasing the size of a civil service or its budget (Niskane, 1974). In this case, bureaucrats could be much more politically active than the public and take advantage of their positions to maximize their impact in the political arena (Wise 2004). 
The new public management (NPM) movement, which began in the late 1970s and early 1980s and is grounded in, rational choice, public-choice theory, and managerialism, seems to reintroduce the dichotomy. The reformers in the NPM movement suggested "public managers are urged to "steer, not row" their organizations" and "public administration is politically neutral, valuing the ideal of neutral competence” (Denhardt \& Denhardt 2000, 551; Frederickson 1996; Gruening 2001; Kelly 1998). Even though the reformers attempted to keep public officials out of from politics, the practice and theory are inconsistent with the dichotomy, such as performance contracting and public-choice theory, respectively (Kaboolian 1998).

In sum, career public officials cannot be politically neutral and may be free to have their own political ideology, in both theory and practice. According to US Gallup Daily tracking in 2010, among unionized federal government employees, $27.2 \%$ of employees identified themselves as republican, $39.5 \%$ of employees as democrat, and 31.4\% of employees as independent. Among nonunionized federal employees, 32.5\% of employees answered she/he is republican, $29.3 \%$ of employees as democrat, and $36.3 \%$ of workers as independent ${ }^{4}$. In general, federal employees are more supportive to the Democratic Party because the party is more generous to federal employees (Davidson 2014).

The two primary political parties in the U.S. have a wide range of differing philosophies and ideals on diverse issues such as role of government, size of government, taxation, health care, immigration, military, gun control, federal employee's pension system, among others. Congruence and incongruence on political ideology between career bureaucrats and political appointees therefore could

\footnotetext{
${ }^{4}$ Gallup. (2011). Democrats Lead Ranks of Both Union and State Workers. Retrieved April 23, 2015, from Gallup http://www.gallup.com/poll/146786/democrats-lead-ranksunion-state-workers.aspx
} 
influence the bureaucratic behaviors of career public officials. As Golden (2000) mentioned, career civil servants might be more loyal or cooperative when they hold the same policy believe as the president; however, public officials may neglect or resist a president's policy agenda when they do not share a political ideology with the president. In a similar vein, career public officials may be more loyal or cooperative when the political appointees in their departments hold similar political ideology. In contrast, those public officials might show negative or passive behaviors in the organization when their political ideology is not congruent with that of their political appointees.

In the next section, we present bureaucratic accountability based on whom public officials are accountable to as the second dimension to understand bureaucratic behaviors.

\section{Bureaucratic Accountability: To whom bureaucrats are accountable?}

Accountability is fundamental in a democratic government, although scholars have yet to reach the consensus on meaning of accountability (Bovens, 2007; Brandsma and Schillemans, 2012; Finer, 1936). Scholars use their own specific meanings of accountability or use the terms transparency, responsiveness, integrity, responsibility, democracy, or efficiency to mean accountability (Bovens, 2007; Brandsma and Schillemans, 2012). However, there is a common ground embedded in meanings of accountability produced by scholars: "an obligation to explain and justify conduct” (Bovens, 2007. p. 450).

The obligation lies between the actor (accountor) and the forum (the accountee); the accountor must inform or explain his conduct to the accountee, followed by discussion to evaluate the accountor's conduct. In the end, sanctions, 
either formal or informal, and either positive or negative, are imposed based on the evaluation (Brandsma and Schillemans, 2012). In other words, accountability is established by going through three stages of information, discussion, and consequences, and accounting for these steps. Boven (2007) defines accountability as "a relationship between an actor and a forum, in which the actor has an obligation to explain and to justify his or her conduct, the forum can pose questions and pass judgment, and the actor ma face consequences” (450).

Traditionally, accountability is understood as the methods to control the discretion of both political appointees and career bureaucrats. There are five different methods: legal constraints, fiscal constraints, political constraints, efficiency norms, and hierarchical control (Radin, 2002). Each method uses a different mechanism such as rules or regulations for confining bureaucrats' behaviors or budget uses, political agenda-setting, maximizing efficiency, or the institution of a chain of command (Radin, 2002). Radin (2002) extends the discussion of accountability from control to expectations. She argues that cabinet secretaries juggle three different expectations: policy expectations, political expectations, and management and internal process expectations. First, policies have different requirements, and cabinet secretaries uphold accountability by fulfilling policies (Radin, 2002). Second, the system of the separation of the three powers (administrative, legislative, and judicial) provides different, and sometimes conflicting, political expectations of cabinet secretaries, and cabinet secretaries uphold accountability by attempting to meet all the political expectations (Radin, 2002). Lastly, cabinet secretaries uphold accountability by meeting the expectations of managing the internal process of their organizations (Radin, 2002). Radin concludes that the three accountability expectations define cabinet officials’ day-to-day behavior. 
Scholars further investigate sub-dimensions of accountability. For instance, Romzek and Dubnick (1987) use two factors, source of agency control and degree of control over agency actions, to extend the concept of accountability to four types: bureaucratic, legal, professional, and political accountability. Accordingly, both bureaucratic accountability and legal accountability intensively control a wide range of public agency activities, but the expectation for bureaucratic accountability is shaped by bureaucratic hierarchy while the expectation for legal accountability is shaped by external party in a position to impose legal sanctions or obligations. Meanwhile, professional accountability and political accountability delegate authority to public administrators instead of intensive supervisory control (Romzek and Dubnick, 1987). In a professional-accountability organization, public managers in charge of their subordinates are laypersons and the subordinates, the public administrators, are the experts who make important decisions (Romzek and Dubnick, 1987). Thus, the source of agency control comes from public administrators’ professional norms and expertise (Romzek and Dubnick, 1987). Likewise, the bureaucracy’s supervisors exhibit less control over public administrators, and expectations for political accountability are shaped to respond to their constituents by reflecting political demands (Romzek and Dubnick, 1987).

A core issue that determines multiple accountability relations is related to multiple dyadic relationships between the accountor and the accountee, which is well understood as a principal-agent model (Boven, 2007; Brandsma and Schillemans, 2012). Here, the accountee is a principal and the accountor is an agent. The accountee delegates his authority to the accountor, whom the accountee screens, selects, and monitors. The accountor takes actions on behalf of the accountee. In a democratic government, the accountor is clear-the public bureaucrats. However, determining 
the accountee makes discussion on accountability complicated. The accountee could be political leaders or appointees, or the general public. This distinction is rooted in the ever-lasting discussion on the administration-politics dichotomy. For those who distinguish administration from politics, politics sets goals and directions expressed by the political process, mainly through elections, and administration is the vehicle that executes those goals and directions (Goodnow, 1900; Jackson, 2009; Wilson, 1887). It follows that bureaucrats are politically neutral and accountable to political leaders and their appointees who are, in turn, accountable to the public and checked by the public through elections. Meanwhile, others do not separate administration from politics and regard administrators as political advocates who design and implement public policies based on their professional norms and, broadly, the public interest (Appleby, 1949; Mulgan, 2000; Romzek and Dubnick, 1987; Waldo, 1948).

The distinction between administration and politics leads to the famous Friedrich-Finer debates in the later 1930s and early 1940s. Friedrich ([1940]1965) posits that administration and politics are not mutually exclusive or absolutely distinct. To him, "public policy is being formed as it is being executed" (167). He further argues that administration is an official's action “in the name of public interest” (167). Friedrich disagrees with effectiveness of a public bureaucrat's political accountability by arguing that "political responsibility based upon the election of legislature and chief executives [has not]succeeded in permeating a highly technical, differentiated government service” (168). He believes many policies are complex, evolving steadily over time, and public bureaucrats are those who participate in the evolving processes. As a result, public bureaucrats know more about the policies than political leaders. Thus, public bureaucrats can uphold accountability toward policies when they rely on 
their own professional expertise and interpret popular sentiment (Friedrich, [1940]1965).

In response to Friedrich, Finer ([1941], 1965) states that “ [w]hile professional standards, duty to the public, and pursuit of technological efficiency are factors in sound administrative operation, they are but ingredients, and not continuously motivating factors, of sound policy, and they require public and political control and direction” (350). He further argues that public servants should not make their own directions; rather they should be accountable to the elected representatives of the public because responsibility necessarily requires obedience to an external controlling authority (Finer, 1936). In a democratic government, according to Finer (1941), the public expresses its wants through elections, and elected representatives should control unelected career bureaucrats in the name of democracy. Finer's view on accountability is rooted in the administration-politics distinction. Finer (1941), in contrast to Friedrich ([1940]1965), draws a sharp line between administration and politics. He asserts that the object or scope of administration is determined not by administrators but by legislature, and administration functions only as the legislature says so.

In sum, Friedrich emphasizes public administrators’ internal control by following professional values and knowledge as well as interpreting public sentiment, while Finer stresses the public administrators' subordination to elected institutions by which the preferences of the public are expressed (Dunn and Legge, 2000). Since a series of exchange of discussion between Friedrich and Finer, scholars today are undecided on this matter; some stand by Friedrich (Campbell and Halligan 1992, 194; King and Stivers 1998a and1998b; Foley 1998; Wamsley 1990, 128; Zanetti 1998) 
while others support Finer (Hyneman 1950, 6; Kernaghan and Langford 1990; Lowi 1993 and 1995; Rose 1987).

The current study does not take one position over the other; rather, with admitting the two pillars of accountability ideas, we leave decisions to bureaucrats in practice. Instead, we use Friedrich’s and Finer’s views on accountability as one critical dimension to understand bureaucrats’ behavior.

\section{Bureaucratic Behavior in the Political View and Accountability Nexus: An Integrated Model}

As discussed so far, bureaucrats may or may not have political views congruent with their overhead political principals. Also, bureaucrats have two choices of accountability: accountability to overhead political principals and accountability to the public. Given two conditions, this study draws four possible bureaucratic responses - loyalty, voice, silence, and exit. The original ideas of voice, exit, and loyalty are from Hirschman (1970), but this study modifies the ideas as Hirschman's ideas assume organizational decline while this study does not. The following sections explain how bureaucrats respond to four different situations.

\section{Loyalty}

Hirschman (1970) introduces the concept of loyalty to explain the conditions of exit and voice. He argues that loyalty is less likely to lead to exit and more likely to lead to voice when 1) "the extent to which customer-members are willing to trade off the certainty of exit against the uncertainties of an improvement in the deteriorated product; and 2) the estimate customer-members have of their ability to influence the 
organization” (77). He further posits that when exit is an available option, organizational members choose the voice option when they are loyal to their organizations. Organizational members are loyal to their organizations when they have enough influence to get the situation back on the right track (Hirschman, 1970). Even if organizational members are not influential, they can still be loyal to their organizations when they expect that conditions will improve (Hirschman, 1970). In summary, Hirschman's (1970) concept of loyalty is a constructive, but passive, reaction to organizational decline with employees' hope that conditions will improve (Farrell and Rusbult, 1992).

Many scholars have had difficulty applying Hirschman’s (1970) conceptualization of loyalty to their research (Golden, 1992). For instance, de Graaf (2010) states that Hirschman’s loyalty is to organizations, and depending on objects of loyalty, Hirschman's concept of loyalty may or may not be adequate. de Graaf contends that "(1) the subject identifies the object of loyalty (the cause) and (2) the subject behaves in a way that promotes the interests of the object of loyalty” (289), and identifies five different objects of loyalty: loyalty to 1) superiors and orders (hierarchical loyalty), 2) conscience and personal ethics (personal loyalty), 3) peers and social norms (social loyalty), 4) profession and professional ethics (professional loyalty), and 5) citizens and civic values (civic loyalty). To de Graaf, loyalty is "the willing and practical dedication of a person to an object (289).

Golden (2010) extends the discussion of loyalty to the context of bureaucrats. Overhead political principals set policies favoring their next election; thus, policies are inevitably political. Golden expects that bureaucrats' are loyal to their overhead political principals when bureaucrats agree with overhead political principals’ policies. As Aberbach and Rockman (1976) observed that not every federal agency suffers 
from "clashing belief” between bureaucrats and overhead political principals, some bureaucrats share the same political ideology with their overhead political principals, albeit they are politically neutral. As a result, when bureaucrats agree with the political ideas behind policies set by their overhead political principals, bureaucrats are loyal to and cooperate with their overhead political principals (Golden, 2010). Golden (2010) also contends that bureaucrats’ loyalty accounts for the possibility that bureaucrats abide by a doctrine of "loyalty to presidency,” regardless of their political ideology (33). However, this study distinguishes active loyalty and passive loyalty (later called silence), and bureaucrats show active loyalty when they are truly motivated by a doctrine of "loyalty to presidency," in other words they are accountable to overhead political principals and share the congruent political ideology behind policies.

\section{Voice}

The second bureaucratic response that depends on the source of accountability and political ideology congruence between career bureaucrats and political appointees is voice. Hirschman $(1970,30)$ defined voice as "any attempt at all to change, rather than to escape from, an objectionable state of affairs, whether through individual or collective petition to the management directly in charge, through appeal to higher authority with the intention of forcing a change in management, or through various types of action and protest, including those that are meant to mobilize public opinion.” Types of behaviors in the voice response include "discussing problems with the supervisor or co-workers; taking action to solve problems; suggesting solutions; seeking help from an outside agency; whistle-blowing” (Farrell and Rusbult 1992, 2020). 
Even Hirschman developed the voice response to explain customers’ dissatisfaction with private organizations, many studies in the public management field have adopted the concept to describe bureaucrats’ behavior (Farrell \& Rusbult 1992; Golden 1992; Whitford \& Lee 2014). According to Golden (1992), when career public officials disagree over the policy procedure for political appointees, they present their disagreements directly in face-to-face meetings or write memoranda outlining their different perspectives. A group of public officials who are the same opinion on a specific policy can also respond through collective action. Another option is whistleblowing, which is "disclosure by organization members (former or current) of illegal, immoral, and illegitimate practices under the control of their employers, to persons or organizations that may be able to effect action” (Near \& Miceli 1985, 4). Public officials can reveal inappropriate practices to Congress, news media, interest groups, or other government agencies. The last response is sabotage, which is defined "the act of destroying or damaging something deliberately so that it does not work correctly” (Merriam-Webster). Sabotage, however, is barely used in the public-administration field (Golden 1992).

Hegedoorn (1999) divides voice into two forms: considerate voice and aggressive voice. The former “attempts to solve the problem considering one’s own concerns as well as those of the organization," and the latter is "efforts to win without consideration for the concerns of the organization” (p. 311)

In this study, we present voice as a bureaucratic response wherein bureaucrats think they are accountable to the political appointee but disagree with policy ideology of the political appointee. Depending on their personalities and organizational context, public officials might show various types of voice mentioned above. 


\section{Silence}

While Hirschman (1970) did not introduce the concept of silence, scholars developed the concept of silence or neglect as a fourth category of bureaucratic behavior. Scholars define neglect as negligent behaviors wherein an organizational member passively allows conditions to worsen (Farrell, 1983; Farrell and Rusbult, 1992). Neglect is destructive to the relationship between an employee and an organization and passive as to the problem at hand (Farrell and Rusbult, 1992). Neglectful behavior often results in lateness (Alder and Golan, 1982, Angle and Perry, 1981; Farrell, 1983; Farrell and Robb, 1980), absenteeism (Farrell, 1983; Hammer, Landau, and Stern, 1981), and higher error rates (Farrell, 1983; Petty and Bruning, 1980).

Golden (1992) also introduces the neglect option as a fourth category in her research to understand bureaucratic responses to presidential control during the Reagan administration. Golden, however, argues that the concept of neglect identified as passive resistance by previous scholars, is rather sabotage, which should be distinguished from “neglect.” To her, neglect is a response wherein bureaucrats do not agree with policy set by overhead political principal but do not resist it either. That is, bureaucrats cooperate with their overhead political principals because of apathy or inertia even if they are not pleased with ideas of their overhead political principals (Golden, 1992). The neglect option is shown as a form of less arguing, acting, or initiating by the bureaucrats (Golden, 1992).

In this study, we introduce silence as a bureaucratic response wherein bureaucrats think they are accountable to the public and their views happen to coincide with policy ideas of overhead political principal. The silence option is different from the neglect option adopted by previous research. Unlike passive, destructive negligence with a hope that situations worsen, the silence in this study 
assumes that bureaucrats expect the success of the policies not for overhead political principals but for the public. The silence option is also different from the concept of neglect by Golden (1992). Unlike bureaucratic cooperation with overhead political principals due to apathy or inertia, bureaucrats in silently and tacitly agree with the direction of policies set by overhead political principals. They agree with the policies because they think the policies reflect what the public wants. Thus, bureaucrats keep silent. However, bureaucrats in this category are always ready to exit when their overhead political principals change policies in a way which with they think the public does not agree.

\section{Exit}

The last bureaucratic response depending on the origin of accountability and political ideology is exit. Hirschman described exit as “some customers stop buying the firm’s products or some members leave the organization: this is the exit option. As a result, revenues drop, membership declines, and management is impelled to search for ways and means to correct whatever faults have led to exit” (Hirschman 1970, 4). Rusbult et al. (1988) includes "actual quitting the job or leaving the organization voluntarily" and "psychological propensity to leave” - thinking about quitting is also in this category (Naus et al. 2007, 688; Hagedoorn et al. 1999). Farrell \& Rusbult (1992) also include “job movement within and across organizational boundaries” and sabotage in the exit category. Career public officials may show these behaviors when their political ideology does not fit with that of their political appointee.

As Dowding et al. (2000) pointed out, exit could be the most effective way to show discontent with the organization in perfect markets; however, in the monopolysupply like government job market, quitting one's job or leaving the organization is 
rare for career bureaucrats, even when career public officials have incongruent political ideas with their political appointees. According to Farrell \& Rusbult (1992), employees with less job satisfaction, superior job alternatives, and working in an organization less invested in employees, are more likely to exit the organization. Whitford \& Lee (2014) found that satisfaction with organization, individual-level perceptions of management's dedication and pay satisfaction of U.S. federal employees are important motivational factors in deciding whether to quit a job and leave the organization in the U.S. federal government.

In this study, we place the exit wherein career bureaucrats think they are accountable to the public and have an incongruent political ideology with that of their political appointees. We assume that career public officials are more likely to choose the exit option when they think they are accountable to general citizens, rather than political appointees, and when they have a different political ideology from their political appointees.

[Figure 1 about here]

\section{Stay}

The four expected scenarios introduced above assume bureaucrats’ activeness. In other words, bureaucrats may fall in one of the four scenarios and take an action associated with the scenario. However, not every bureaucrat would behave as he or she would believe. Sometimes when bureaucrats face one of the scenarios, passiveness or fear prevent them from taking the associated actions and they do not act at all. Thus, we introduce another dimension — the activeness-passiveness dimension — to the framework developed above. If bureaucrats are active, then we expect that bureaucrats would take an action associated with the scenario that they 
face. However, if bureaucrats are inactive, then we expect that bureaucrats may stay without taking any action. As a result, the option "stay” can be found in all four scenarios. However, the "stay" option is distinguishable from the "silence" option. The "silence" option is an active and intended choice to observe the situation without taking action because bureaucrats’ political view happens to coincide with political appointees' political views. At this point, one can hardly distinguish when bureaucrats take the "silence" option or the "stay" option. However, the difference between the two options becomes evident when political congruence between bureaucrats and political appointees is cracked. Those who take the "silence" option may move toward the "exit" option while those who take the "stay" option will still stay. As a result, we propose a frame as shown in Figure 2 below.

[Figure 2 about here]

\section{Further Discussion}

We have discussed five bureaucratic behaviors depending on the bureaucrats’ political views and the sources of accountability: loyalty, voice, silence, exit, and stay. In this section, we further develop the discussion by adding one more behaviors reflecting the degrees of congruence of political view to political appointees and source of accountability.

[Figure 3 about here]

Figure 3 presents five behavioral patterns of career public officials. Depending on the degree of congruence on political ideology with their political appointee and the 
source of accountability, bureaucrats might show various behaviors even in the loyalty, voice, silence, and exit categories.

In the loyalty category, as the degree of the congruence and the accountability level to political appointees increase, career public officials could passionately cooperate with their political appointees and show them extreme loyalty. This might explain the behavior of "politicos" in the public-choice theory (Wise 2004, 673). On the contrary, as the degree of the congruence and the accountability level to political appointees decrease, career bureaucrats may exhibit more neutral behaviors. In the voice category, as the degree of the incongruence and the accountability level to political appointee increases, the behaviors in the voice category might appear in more aggressive forms, such as whistleblowing or sabotage. In the opposite way, as the degree of the incongruence and the accountability level to political appointees decreases, career public officials more considerately voice their opinions through face-to-face meetings or writing memoranda . In the silence category, as the degree of political ideology congruence and the level of the accountability to the public increases, career bureaucrats might tacitly agree more with the direction of policies determined by the political appointees. When the level of the congruence decreases, neglectful behaviors, such as lateness, absenteeism, and increased error rates, might appear. In the exit category, when career public officials have a higher level of incongruence to the political appointees and think they are more accountable to the public, they may leave the organization. However, as the degree of incongruence and the accountability level to the public weaken, career public officials may think of quitting their jobs, or moving to other departments in the same organization rather than leaving the organization in action. As we examined, the degrees of congruence 
and incongruence of political ideology and the accountability levels to political appointees or the public present more diverse behavioral patterns in each category.

Lastly, we can highlight the neutral behavior of career public officials. In the middle part of the figure, as the degree of the political ideology congruence is close to zero and the level of accountability dimension is close to the center, in between the public and political appointees, career bureaucrats would be more politically neutral and work with objectivity, expertise, and professionalism. This neutral behavior might be quite similar to the bureaucratic behavior of Weber's ideal type of bureaucracy. Considering the Gallop survey in 2011 we previously introduced, there were 31.4\% of employees among unionized federal government employees who responded they are independent and 36.6\% of employees among nonunionized federal employees responded they are independent. We may presume that these public officials might show more neutral behavior than the public officials who clearly present their political identity.

\section{Conclusion}

The current study has contrived bureaucratic behavioral models of career public officials based on congruence or incongruence of political ideology with their overhead political appointees and two sources of accountability: a political appointee and the public. The models proposed six propositions to understand bureaucratic behaviors of career public officials based on the dimensions that have been actively but separately researched in the public administration field. We proposed six behavioral categories partly borrowing the ideas from Hirschman (1970) and Golden 
(1992): loyalty; voice; silence, exit, stay, and neutrality. This study might be the first work to combine the two dimensions in order to understand bureaucratic behaviors.

From these models, we find two new behavioral patterns: stay and neutrality. These two patterns may explain behaviors of public officials who are politically neutral or apolitical, impersonal, and sometimes inactive. These behaviors and the public officials who exhibit them have been considered less important in public organizations. The public officials in this pattern might not think political ideology is important for their careers and private lives, and they may depend more on professional accountability than political accountability. To understand more broad ranges of bureaucratic behaviors we might delve into work motivation drives and organizational behaviors of public officials in this pattern.

This study is a nascent and conceptual work to explain bureaucratic behaviors. Further empirical studies with survey research or case studies should be conducted afterward.

\section{References}

Aberbach, Joel D, and Bert A Rockman. 1976. "Clashing beliefs within the executive branch: The Nixon administration bureaucracy." The American Political Science Review:456-468.

Adler, Seymour, and Jacob Golan. 1981. "Lateness as a withdrawal behavior." Journal of Applied Psychology 66 (5):544.

Angle, Harold L, and James L Perry. 1981. "An empirical assessment of organizational commitment and organizational effectiveness." Administrative Science Quarterly:1-14.

Appleby, Paul H. 1949. Policy and Administration. Alabama: University of Alabama Press.

Bovens, Mark. 2007. "Analysing and assessing accountability: a conceptual framework1." European Law Journal 13 (4):447-468. 
Brandsma, Gijs Jan, and Thomas Schillemans. 2012. "The accountability cube: measuring accountability." Journal of Public Administration Research and Theory:mus034.

Campbell, Colin, and John Halligan. 1992. Politcal Leadership in an Age of Constraints. Sydney: Allen and Unwin.

Cooper, Terry L, Thomas A Bryer, \& Jack W. Meek. 2006. Citizen-centered collaborative public management. Public Administration Review, 66(s1), 7688.

Davidson, Joe. November 3, 2014. Federal unions pushing mostly Democratic candidates, but also some Republicans, The Washington Post. Retrieved from http://www.washingtonpost.com/politics/federal government/federal-unionspushing-mostly-democratic-candidates-but-also-somerepublicans/2014/11/02/a9987354-613b-11e4-9f3a-7e28799e0549_story.html

De Graaf, Gjalt. 2011. "The loyalties of top public administrators." Journal of Public Administration Research and Theory 21 (2):285-306.

Denhardt, Robert B, \& Janet Vinzant Denhardt. 2000. The new public service: Serving rather than steering. Public Administration Review, 60(6), 549-559.

Dowding, Keith, Peter John, Thanos Mergoupis, \& Mark Vugt. 2000. Exit, voice and loyalty: Analytic and empirical developments. European Journal of Political Research, 37(4), 469-495.

Dunn, Delmer D, and Jerome S Legge. 2001. "US local government managers and the complexity of responsibility and accountability in democratic governance." Journal of Public Administration Research and Theory 11 (1):73-88.

Farrell, D, and DL Robb. 1980. "Lateness to work: A study of withdrawal from work." Annual meeting of the Academy of Management, Detroit.

Farrell, Dan. 1983. "Exit, voice, loyalty, and neglect as responses to job dissatisfaction: A multidimensional scaling study." Academy of Management Journal 26 (4):596-607.

Farrell, Dan, and Caryl E Rusbult. 1992. "Exploring the exit, voice, loyalty, and neglect typology: The influence of job satisfaction, quality of alternatives, and investment size." Employee Responsibilities and Rights Journal 5 (3):201-218.

Finer, Herman. 1936. "Better government personnel." Political Science Quarterly:569-599.

Foley, Delores. 1998. "We Want Your Input: Dilemmas of Citizens Participation." In Government is Us, edited by Cheryl Simerll King and Camilla Stivers. Thousand Oaks,CA: SAGE.

Frederickson, H George. 1996. Comparing the reinventing government movement with the new public administration. Public Administration Review, 263-270.

Friederich, Carl. [1940]1965. "Public Policy and the Nature of Administrative Responsibility." In Bureaucratic Power in National Politics, edited by Francis Rourke, 165-175. Bostron: Little, Brown and Company.

Fry, Brian R, \& Llyoyd G. Nigro.1996. Max Weber and US public administration: the administrator as neutral servant. Journal of Management History, 2(1), 37-46.

Golden, Marissa Martino. 1992. "Exit, voice, loyalty, and neglect: Bureaucratic responses to presidential control during the Reagan administration." Journal of Public Administration Research and Theory 2 (1):29-62.

Golden, Marissa Martino. 2000. What Motivates Bureaucrats?: Politics and Administration During the Reagan Years. New York: Columbia University Press.

Goodnow, Frank J. 1900. Politics and Administration. New York: Russell and Russell. 
Goodnow, Frank J. 1900. Politics and Administration. In J. M. Shafritz, A. C. Hyde \& S. J. Parkes (Eds.), Classics of Public Administration (5th ed., pp. 35-37). Belmont, CA: Wadsworth/Thomson Learning.

Gruening, Gernod. 2001. Origin and theoretical basis of New Public Management. International public management journal, 4(1), 1-25.

Hagedoorn, Mariët, Van Yperen, Nico W, Van de Vliert, Evert, \& Buunk, Bram P. 1999. Employees' reactions to problematic events: A circumplex structure of five categories of responses, and the role of job satisfaction. Journal of Organizational Behavior, 20(3), 309-321.

Hammer, Tove H, Jacqueline C Landau, and Robert N Stern. 1981. "Absenteeism when workers have a voice: The case of employee ownership." Journal of Applied Psychology 66 (5):561.

Heyneman. 1950. Bureaucracy in a Democracy. New York: Harper and Brothers. Hirschman, Albert. 1970. Exit, Voice, and Loyalty: Responses to Decline in Firms, Organizations, and States. Cambridge, MA: Harvard University Press.

Jackson, Michael. 2009. "Responsibility versus accountability in the Friedrich-Finer debate." Journal of Management History 15 (1):66-77.

Jensen, Jason L, Sum, Paul E, \& Flynn, David T. (2009). Political orientations and behavior of public employees: a cross-national comparison. Journal of public administration research and theory, 19(4), 709-730.

Kaboolian, Linda. 1998. The new public management: Challenging the boundaries of the management vs. administration debate. Public Administration Review, 189-193.

Kelly, Rita Mae. 1998. An inclusive democratic polity, representative bureaucracies, and the new public management. Public Administration Review, 201-208.

Kernahan, Kenneth, and John Langford. 1990. The Responsible Public Servant. Halifax: Institute for Research on Public Policy.

King, Cheryl Simerll, and Camilla Stivers. 1998a. "Citizens and Administrators: Roles and Relationships." In Government is Us, edited by Cheryl Simerll King and Camilla Stivers. Thousand Oaks, CA: SAGE.

King, Cheryl Simerll, and Camilla Stivers. 1998b. "Conclusions: Strategies for an Anti-Government Era." In Government is Us, edited by Cheryl Simerll King and Camilla Stivers. Thousand Oaks, CA: SAGE.

Lowi, Theodore. 1995. Lowi responds. JSTOR.

Lowi, Theodore J. 1993. "Legitimizing public administration: A disturbed dissent." Public Administration Review:261-264.

Martino, Marissa. 2012. What Motivates Bureaucrats?: Politics and Administration During the Reagan Years: Columbia University Press.

Mulgan, Richard. 2000. "‘Accountability’: An Ever-Expanding Concept?" Public Administration 78 (3):555-573.

Naus, Fons, van Iterson, Ad, \& Roe, Robert. 2007. Organizational cynicism: Extending the exit, voice, loyalty, and neglect model of employees' responses to adverse conditions in the workplace. Human Relations, 60(5), 683-718.

Near, Janet P, \& Marcia P Miceli. 1985. Organizational dissidence: The case of whistle-blowing. Journal of Business Ethics, 4(1), 1-16.

Nigro, Lloyd G., Felix Nigro, and J. Edward Kellough. 2007. The New Public Personnel Administration. Boston: Wadsworth, Cengage Learning. 
O'Toole Jr, Laurence J. 1987. Doctrines and developments: Separation of powers, the politics-administration dichotomy, and the rise of the administrative state. Public Administration Review, 17-25.

Petty, MM, and Nealia S Bruning. 1980. "A comparison of the relationships between subordinates' perceptions of supervisory behavior and measures of subordinates' job satisfaction for male and female leaders." Academy of Management Journal 23 (4):717-725.

Romzek, Barbara S, and Melvin J. Dubnick. 1987. "Accountability in the public sector: Lessons from the Challenger tragedy." Public Administration Review:227-238.

Rose, Richard. 1987. "Giving Direction to Permanent Officials: Signals from the Electorate, the Market, Laws, and Expertise." In Bureaucracy and Public Choice, edited by Jan-Erik Lane. Newbury Park, CA: SAGE.

Rosenbloom, David. 2008. The politics-administration dichotomy in US historical context. Public Administration Review, 68(1), 57-60.

Rosenbloom, David H. 1993. Editorial: Have an Administrative Rx? Don't Forget the Politics! Public Administration Review, 503-507.

Rusbult, Caryl E, Farrell, Dan, Rogers, Glen, \& Mainous, Arch G. 1988. Impact of exchange variables on exit, voice, loyalty, and neglect: An integrative model of responses to declining job satisfaction. Academy of Management Journal, 31(3), 599-627.

Svara, James H. 1985. Dichotomy and duality: Reconceptualizing the relationship between policy and administration in council-manager cities. Public Administration Review, 221-232.

Svara, James H. 2001. The myth of the dichotomy: Complementarity of politics and administration in the past and future of public administration. Public Administration Review, 61(2), 176-183.

Waldo, Dwight. 1948. The Administrative State. New York: Ronald.

Wamsley, G. 1990. "The Agency Perspective: Public Adminsitrators as Agential Leaders." In Refounding Public Administration, edited by G. Wamsley, Bacher, R., Goodsell, C., Kronenberg, P., Rohr, J., Stivers, C., White, O., Wolf, J. Newbury Park: Sage.

Whicker, Marcia Lynn, Dorothy Olshfski \& Ruth Ann Strickland. 1993. The troublesome cleft: Public administration and political science. Public Administration Review, 531-541.

Whitford, Andrew B, \& Lee, Soo-Young. 2014. Exit, voice, and loyalty with multiple exit options: Evidence from the US federal workforce. Journal of public administration research and theory, muu004.

Wilson, Woodrow. 1887. "The Study of Administration." Political Science Quarterly 2:197-222.

Wise, Lois Recascino. 2004. Bureaucratic posture: On the need for a composite theory of bureaucratic behavior. Public Administration Review, 64(6), 669-680.

Zanetti, Lisa. 1998. "At the Nexus of State and Civil Society: The Transformative Practice of Public Administration." In Government is Us, edited by Cheryl Simerll King and Camilla Stivers. Thousand Oaks, CA: SAGE. 
Figure 1. Bureaucratic Behavior in the Political View and Accountability Nexus

\begin{tabular}{|c|c|c|c|}
\hline & & \multicolumn{2}{|c|}{ Accountability } \\
\hline \multirow{2}{*}{ Political View } & Congruence & The Public & Political Appointee \\
\cline { 2 - 4 } & & Silence & Loyalty \\
& Incongruence & Exit & Voice \\
\hline
\end{tabular}


Figure 2. The Active-Passive Dimension in the Model: The Unseen Behavior

\begin{tabular}{|c|c|c|c|}
\hline & \multicolumn{2}{|c|}{ Accountability } \\
\hline & & The Public & Political Appointee \\
\hline \multirow{2}{*}{$\begin{array}{l}\text { Political } \\
\text { View }\end{array}$} & Congruence & $\begin{array}{ll}\text { Silence } & \text { Stay }\end{array}$ & Loyalty \\
\hline & Incongruence & $\begin{array}{l}\text { Exit } \\
\text { Stay }\end{array}$ & $\begin{array}{ll}\text { Voice } & \text { Stay }\end{array}$ \\
\hline
\end{tabular}


Figure 3. Five Behavioral Patterns of Career Public Officials

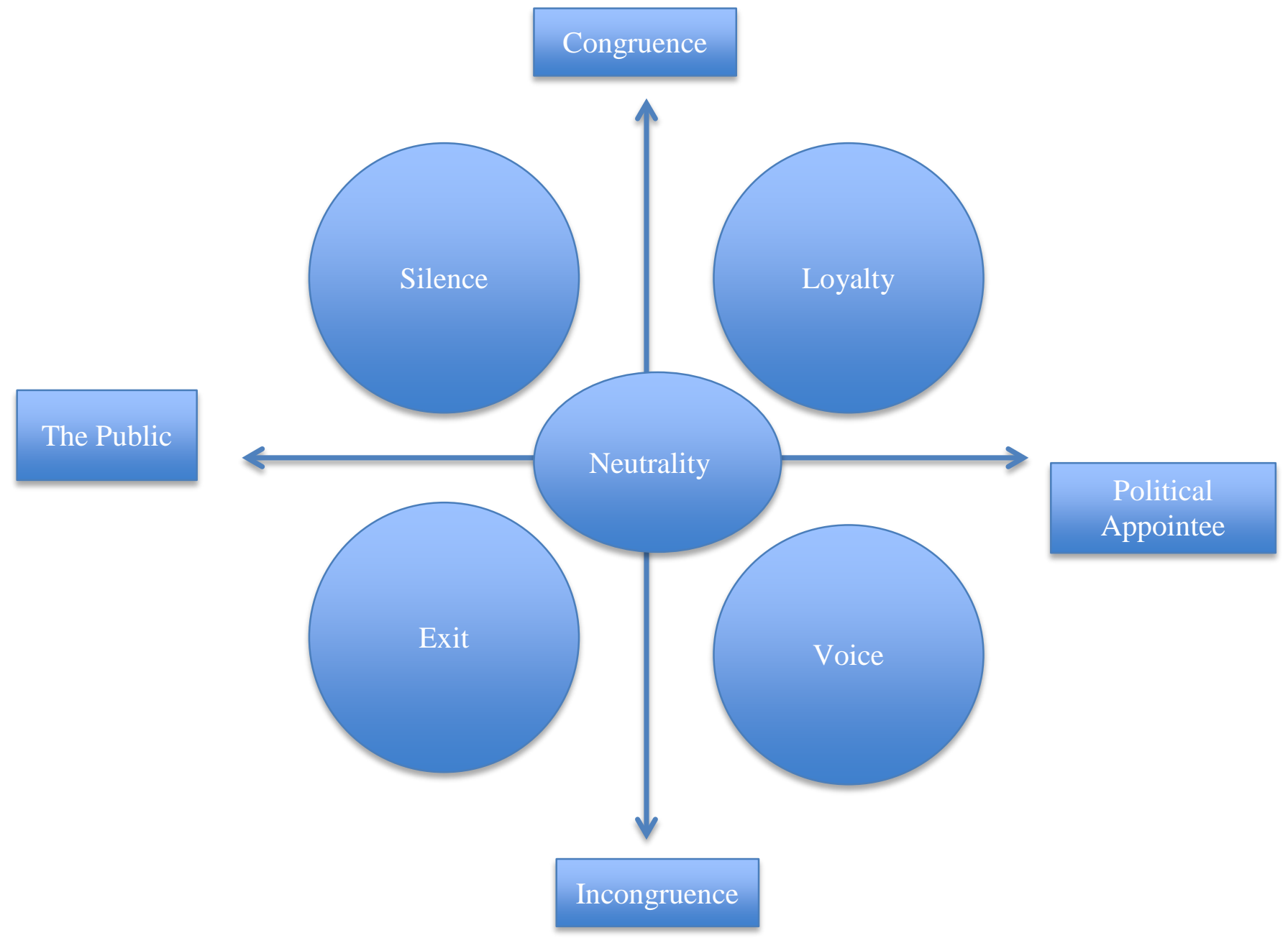

